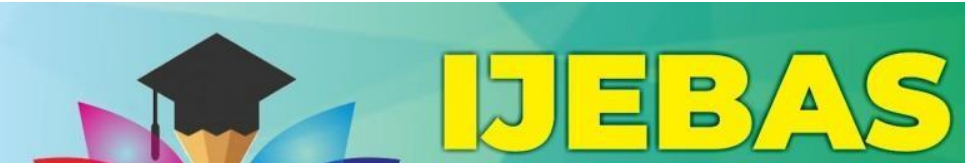

International journal of Economic, Business,

\title{
ANALYSIS OF DIFFERENCES IN TRANSFORMATIONAL LEADERSHIP BETWEEN GENERATIONS X AND Y AND THE EFFECT ON POWER PLANT COMPANY PERFORMANCE
}

\author{
Ilma Azam Firman Syatoto \\ Universitas Sumatera Utara, Medan, Indonesia \\ E-mail: ilmaazam@gmail.com
}

\begin{abstract}
This study analyzes the differences in transformational leadership between generation $X$ and generation $Y$ and its effect on company performance in two power generation companies in North Sumatra Province. The number of samples was 50 people in each group of generations $X$ and Y. Data analysis using SPSS included F-test, T-test, the coefficient of determination, and independent sample T-test. The F-test shows that charismatic variables, inspirational motivation, intellectual stimulation, and individual considerations simultaneously affect the performance of each group of generation $X$ and generation $Y$. The results of the T-test in generation $X$ show that the variables of inspirational motivation and individual considerations are partially has a positive and significant effect on company performance, meanwhile in generation $Y$ only charismatic variables have a positive and significant influence on company performance. The results of the coefficient of determination said that the transformational leadership of generation $X$ contributed $70.2 \%$ to the company performance, while the transformational leadership of the $Y$ generation contributed $22.3 \%$ to the company performance. Independent sample T-test said that there was a significant difference between the transformational leadership of the generation $X$ and generation $Y$.
\end{abstract}

Keywords: Company Performance, Generation X, Generation Y, Transformational Leadership

\section{INTRODUCTION}

North Sumatra has several power generation companies. Two of them are Power Plant A (PPA) and Power Plant B (PPB). PPA is a power generation company that has a power capacity of 1000 Megawatts, which in its operations uses gas fuel. Meanwhile, PPB is a power plant that uses coal fuel, which in its capacity of 140 Megawatts. PPA has the type of Gas and steam power plant, and diesel power plant. While PPB has only the steam power plant. Based on the data obtained and interviews in the PPA and PPB companies, the results of leadership perspective and company performance between PPA and PPB differs in the range of 2016 to 2019.

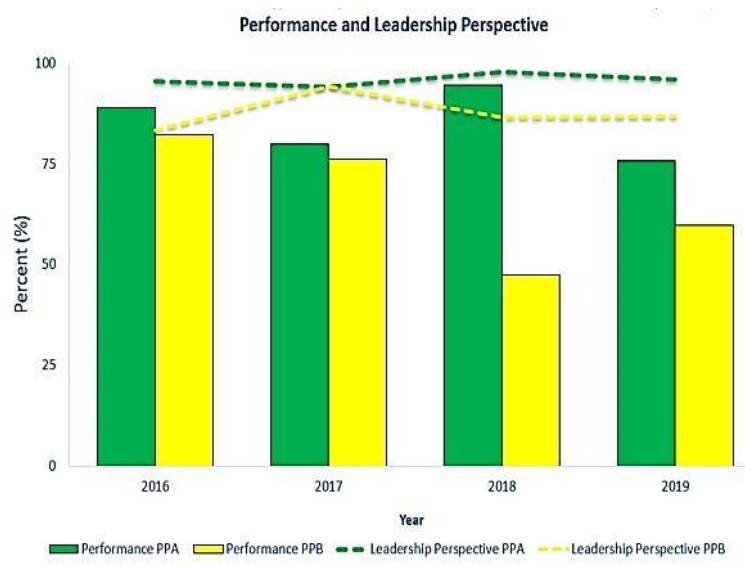

Figure 1 Performance and Leadership Perspective

International Journal of Economic, Business, Accounting, Agriculture Management and Sharia Administration |IJEBAS 
Analysis Of Differences In Transformational Leadership Between Generations X And Y And The Effect On Power Plant Company Performance

DOI: $10.54443 /$ ijebas.v1i2.109

It is explained in Figure 1 that the achievements of PPA and PPB have differences. Based on the PPA leadership perspective has a trend of higher values than PPB in the range of 2016 to 2019. Likewise, the comparison of company performance between PPA and PPBin the same year. Figure 1 shows that leadership indirectly affects the achievement of the company performance value of the two power generation companies. Another phenomenon between PPA and PPB companies is the composition of structural employees.

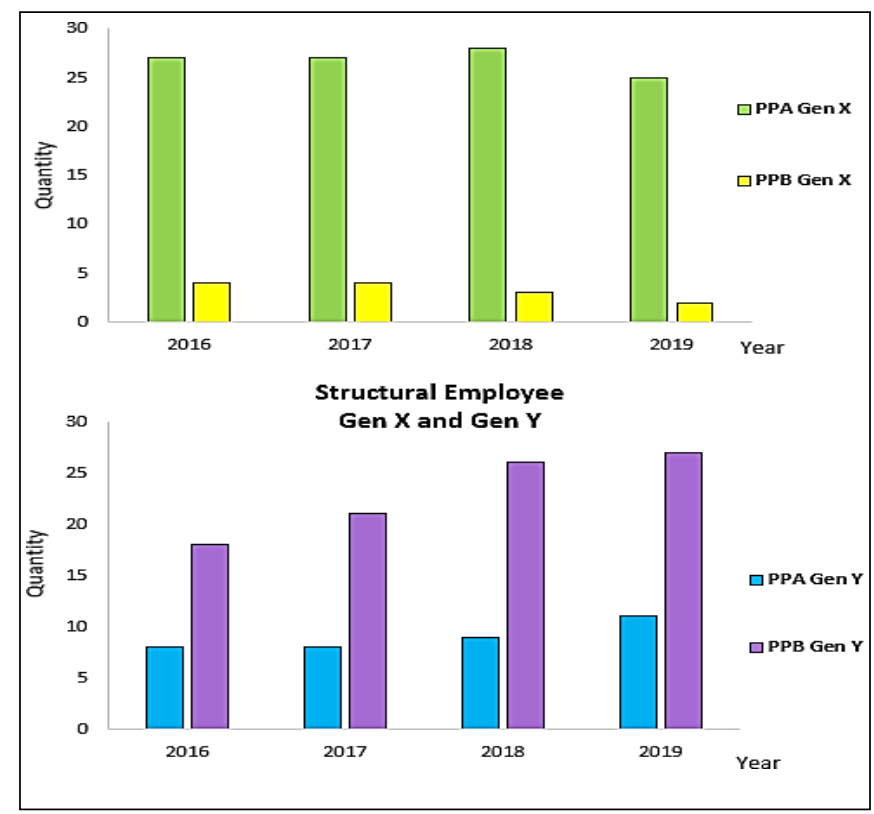

Figure 2 Structural Employee Gen X and Gen Y

Figure 2 explains that from 2016 to 2019 shows that the ratio of structural employees from generations X and Y in PPA and PPB companies. In the span of 2016 to 2019, PPA was dominated by Generation X, in contrast to PPB in the same year, structural employees at PPB were dominated by Generation Y. In these two generations, they mostly occupy the low managerial level or often called the supervisor.

\section{LITERATURE REVIEW}

\subsection{Transformational Leadership}

Bass \& Avolio, 1994 and Northouse, 2004 mean that transformational leadership is a collaborative leadership style that produces change through involvement, connection, and motivation. The attributes that make up transformational leadership are idealized influence, individual judgment, inspirational motivation, and intellectual stimulation. Transformational leadership is a leadership theory that is effective in any situation or culture (Yukl, 2006). The components of transformational leadership, as defined by Bass and Avolio (1994), consist of idealized influence, individualized consideration, inspirational motivation, and intellectual stimulation.

\subsection{Idealized/Charismatic Influence}

Bass and Avolio (1994) and Bass and Riggio (2006) argue that leaders become role models for change, exhibit charismatic, high moral standards, and ethical practices. Furthermore, Bell and Narz (2007) found that leaders do not have false pride and are loyal to ethics, goals, and personal principles. Bass and Riggio explain that role models are admired, trusted, and respected; on the other hand, followers want to imitate the leader's behavior. According to Bass and Avolio (1994) leaders who exhibit idealized influence embrace integrity and principles-based behavior. 


\subsection{Inspirational Motivation}

Leaders with the ability to inspire others to join in on a shared vision are considered to use inspirational motivation. Bass and Riggio (2006) assert that this type of leader imagines the future and, through motivation and inspiration, followers join in imagining the future. According to Bass and Avolio (1994) leaders create an enthusiastic and enthusiastic environment. Tichy and Devanna (1990) agree that motivation and role modeling are key behaviors for inspirational motivation.

\subsection{Intellectual Stimulation}

Intellectual stimulation is a leadership style that energizes followers by challenging their imagination and expanding their creative ability to solve problems (Bass \& Avolio, 1994; Bass \& Riggio, 2006; Northouse, 2004). These leaders do not criticize followers openly, instead they encourage the identification of new ideas. Bass adds that these leaders challenge followers to use intelligence to identify new solutions.

\subsection{Individual Considerations}

An important factor for transformational leaders is knowing the needs of followers. Bass and Riggio (2006) and Northouse (2004) state this is provided through coaching, advisoring, and mentoring. Furthermore, Bass and Riggio state that followers are developedthrough the recognition of individual needs by the leader.

\subsection{Performance}

Castka, Bamber, Sharp and Belohoubek (2001) mention performance as the goal of teamwork and they state that team performance has become a very important aspect in the field of research. Performance characteristics according to leadership style (Zaccaro, Rittman \& Marks, 2001). In the article Zaccaro et al. (2001) they argue that the leadership process is perhaps the most critical for influencing the performance outcomes of members of different generations. Fiedler (1996) researched that the effective leadership of a leader is a major determinant of the performance of members, groups or organizations.

\subsection{Generation $X$}

Generation X people were born between 1965-1980. Generation X people will not stayin the same workplace for more than five years and in many cases may move within three years (Chatzky, 2002). Generation $X$ works for life and balance of life is the hallmark of this generation (Conger, 2006). Generation $X$ tends to be more independent, motivated, and independent. Furthermore, Kupperschmidt (2000) describes generation $X$ as information technology and is very comfortable with diversity, change, and competition.

\subsection{Generation $Y$}

Often referred to as Generation Y, Echo Boom, Net Generation or Millennials. This group was born between 1981 and 2000 (Lancaster \& Stillman, 2002). The first wave of Millennials entered the workforce in 2004. Millennials have been described as selfish, unmotivated and highly narcissistic (Twenge, J. M., Campbell, W. K., \& Freeman, E. C., 2012). They prefer a group work environment with less formal leadership, a strong focus onresults, and collaboration (Crumpacker \& Crumpacker, 2007).

\section{PREVIOUS RESEARCH}

Keller (2006) analyzed companies in the R\&D field, from the results of the analysis that the charismatic dimensions and intellectual stimulation had an impact on team performance. Studies conducted by Webb (2007) and Tsai, Chen, Cheng (2009) stated that the four dimensions of transformational leadership such as charismatic, inspirational motivation, intellectual stimulation and individual considerations positively affect performance. The research group Malika J, Kristina 
P and Sara C (2020) examined 42 CEOs of US and European public companies. The results showed a significant relationship between intellectual stimulation and inspirational motivation had a positive effect on company performance. Mecca M. Salahuddin (2010) conveyed that different generations practice different ways of leading. Huichun $\mathrm{Yu}$ and Peter Miller (2005) in their research show that the characteristics of leadership styles differ between generations in different industries.

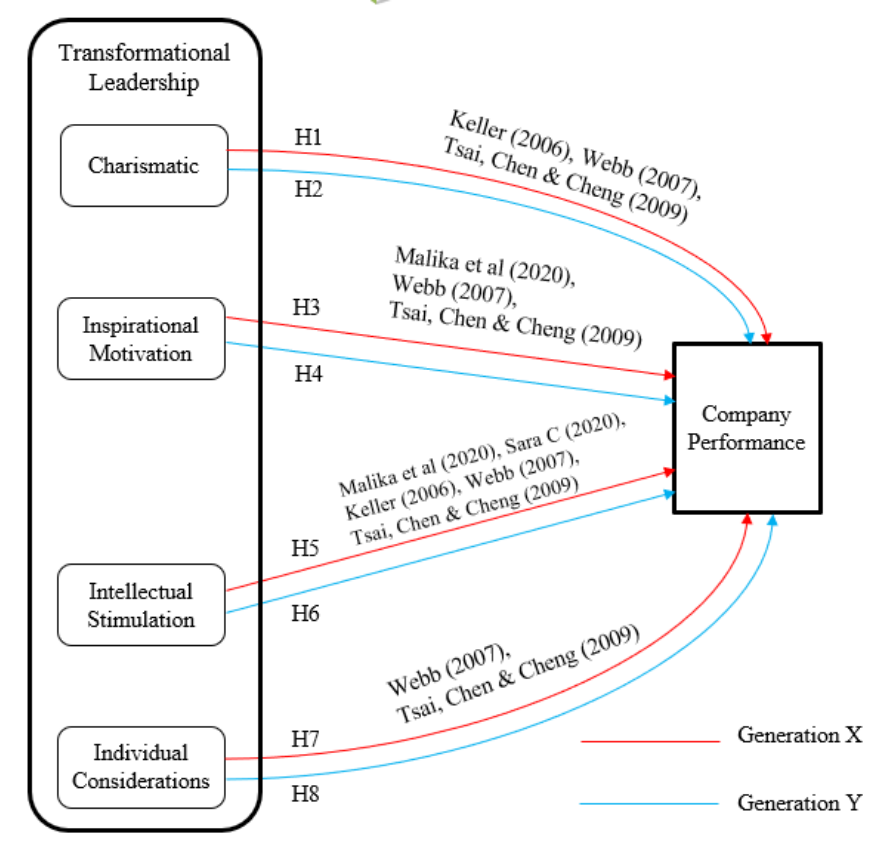

Figure 3 Conceptual Framework

\section{HYPOTHESIS}

As the conceptual framework in Figure 3, the research hypotheses are formulated :

H1: There is a positive and significant influence between the Charismatic of Generation X leaders on company performance

$\mathrm{H} 2$ : There is a positive and significant influence between the Charismatic of Generation Y leaders on company performance

H3. There is a positive and significant influence between the inspirational motivation of Generation X leaders on company performance

H4: There is a positive and significant influence between the inspirational motivation of Generation Y leaders on company performance

H5. There is a positive and significant influence between the intellectual stimulation of Generation X leaders on company performance

H6: There is a positive and significant influence between the intellectual stimulation of Generation Y leaders on company performance

H7. There is a positive and significant influence between the individual considerations of Generation X leaders on company performance

H8: There is a positive and significant influence between the individual considerations of Generation Y leaders on company performance

H9: There are transformational leadership differences between generations $\mathrm{X}$ and generation $\mathrm{Y}$ 


\section{PARTICIPANTS}

In both power generation companies, the population of Generation $\mathrm{X}$ is 56 employees and Generation Y is 290 employees. The research sample for the $\mathrm{X}$ generation is 50 employees and the $\mathrm{Y}$ generation group is 50 employees.

\section{DATA COLLECTION AND QUESTIONNAIRE DESIGN}

Data collection was done by using a questionnaire. Questionnaire is a structured questionnaire in order to obtain accurate data in the form of direct responses from respondents. This instrument identifies the components of transformational leadership (charismatic, inspirational motivation, intellectual stimulation, and individual consideration) and identifies the company performance. The research instrument was first tested for validity and reliability. The sample data were also tested for normality, multicollinearity, heteroscedasticity to provide certainty that the data have accuracy in estimation, are unbiased and consistent. Data analysis using SPSS includes F-test, T-test, Coefficient of Determination test and Independent Sample T-test

\section{EMPIRICAL RESULTS}

The SPSS data analysis is presented in Table 1. The results of the F-test for the $\mathrm{X}$ generation group have a calculated $F$ value of 26,484 and for the $Y$ generation the calculatedF value of 3,225. It is known that the $\mathrm{F}$ table is 2.56 so that based on decision making in theF-test it can be concluded that the variables of Charismatic, Inspirational Motivation, Intellectual Stimulation, Individual Consideration simultaneously affect performance in the $\mathrm{X}$ and $\mathrm{Y}$ generation. In the generation $\mathrm{X}$, variable inspirational motivation and individual considerations partially have a positive and significant effect on company performance, meanwhile in the Y generation group only charismatic variables partially have a positive and significant impact on company performance. The results of the coefficient of determination said that the transformational leadership of generation $\mathrm{X}$ contributed $70.2 \%$ to the company performance, while the transformational leadership of the Y generation contributed $22.3 \%$ to the company performance. The independent sample T-test said that there was a significantdifference between the transformational leadership of the generation $\mathrm{X}$ and generation $\mathrm{Y}$.

\begin{tabular}{cccccc}
\hline \multirow{2}{*}{ Analysis } & \multicolumn{2}{c}{ Generation X } & \multicolumn{2}{c}{ Generation Y } \\
& Sig. & Hypothesis & Sig. & Hypothesis \\
\hline \multirow{3}{*}{ T-test } & 0,805 & H1 rejected & 0,039 & H2 accepted \\
& Inspirational Motivation & 0,000 & H3 accepted & 0,827 & H4 rejected \\
& Intellectual Stimulation & 0,793 & H5 rejected & 0,951 & H6 rejected \\
& Individual Consideration & 0,038 & H7 accepted & 0,381 & H8 rejected \\
\hline \multirow{2}{*}{ F-test } & Gen X transformational & Gen Y transformational \\
& F table $=2,56$ & leadership affects & leadership affects \\
& company performance & company performance \\
& F count $=26,484$ & \multicolumn{2}{c}{ F count $=3,225$} \\
\hline \multirow{2}{*}{ Coefficient of Determination } & \multicolumn{2}{c}{$70,2 \%$} & & $22,3 \%$ \\
\end{tabular}

Independent Sample T-test

Sig $0,000=$ H9 accepted

Table 1 Data Analysis

International Journal of Economic, Business, Accounting, Agriculture Management and Sharia Administration |IJEBAS 


\section{CONCLUSION}

For the Generation X group, the dimensions of transformational leadership that have a positive effect on company performance are the variables of inspirational motivation and individual considerations. According to Bass, B. M., \& Riggio, R. E. (2006) transformationalleaders who have an inspiring motivational dimension behave in ways that motivate and inspire those around them by providing meaning and challenges in their work. Meanwhile, transformational leaders who have dimensions of individual consideration pay more attention to the individual needs of followers to develop. Leaders position themselves as coaches or mentors. Leaders delegate tasks as a means of developing followers. Delegated tasks are monitored to see if followers need additional support and to assess progress but followers do not feel they are being checked. Meanwhile, Generation Y needs transformational leaders who have charisma to influence the company's performance. Charismatic transformational leaders behave by being role models for followers. Followersidentify with the leader and tend to want to emulate. sample items of transformational leaderswith charismatic dimensions as described by Avolio, B., \& Bass, BM (1995) leaders emphasize the importance of having a collective sense of mission, leaders talk about valuesand beliefs, leaders act in a way that builds respect for those around them, leaders considering the moral and ethical consequences of decisions, leaders go beyond self-interestfor the good of the group.

\section{REFERENCES}

Ardichvili, A., \& Manderscheid, S. (2008, October). Emerging practices in leadership development: An introduction. Advances in Developing Human Resources, 10(5), 619-631.

Allen \& Meyer.1997. Commitment In The Workplace (Theory, Research and Application). Sage Publication London.

Avolio, B. J., \& B. M. Bass. (2004). Multifactor leadership questionnaire: Manual and sample set (3rd ed.) Redwood City, ca: Mind Garden.

Bass, B. M., \& Avolio, B. J. (1994). Improving organizational effectiveness through transformational leadership. Thousand Oaks, CA: Sage.

Bass, B. M., Avolio, B. J., Jung, D. I., \& Berson, Y. (2003). Prediction unit performance by assessing transformational and transactional leadership. Journal of Applied Psychology, 88(2), 207-218.

Bass, B. M., \& Riggio, R. E. (2006). Transformational leadership (2nd ed.). Mahwah, NJ: Erlbaum.

Bell, N. S., \& Narz, M. (2007). Meeting the challenges of age diversity in the workplace. The CPA Journal, 77(2), 56-60.

Burns, J. M. (1978). Leadership. New York, NY: Harper \& Row.

Calhoun S.K. \& Strasser P.B. (2005) Generations at work. AAOHN Journal 53 (11), 467-471.

Castka, P., Bamber. C.J., Sharp, J.M., \& Belohoubek, P. (2001). Factors effecting successful implementation of high performance teams. Team Performance Management, 7(7/8), 123.

Chatzky, J. (2002). Gen Xers aren"t slackers after all. Time, 159(14), 87.

Conger, J. (2006). How Gen X'es Manage. Organizational Behavior Reader.

Cragg, R., \& Spurgeon, P. (2007). Competencies of a good leader. Clinician in Management, 15(3/4), 109-114.

Crumpacker, M., J.M. Crumpacker. Succession planning and Generational Stereotypes: Should HR Consider AgeBased Values and Attitudes a Relevant Factor or a Passing Fad? // Public Personnel Management, 2007. í v36. í pp. 349-369. 
Drake, A. R., Wong, J., \& Salter, S. B. (2007). Empowerment, motivation, and performance: Examining the impact of feedback and incentives on nonmanagement employees. Behavioral Research in Accounting, 19(1), 71.

DuBrin, A. J. (2001). Leadership: Research findings, practice, skills (3rd ed.). Boston, ma: HoughtonMifflin.

Duchscher J.E. \& Cowan L. (2004) Multigenerational nurses in the workplace. The Journal of Nursing Administration 34 (11),495-501Fuller, J. B., Morrison, R., Jones, L., Bridger, D., \& Brown, V. (1999). The effects of psychological empowerment on transformational leadership and job satisfaction. The Journal of Social Psychology, 139(3), 389-391.

Dvir, T., D. Eden, B. J. Avolio, \& B. Shamir. (2002). Impact of transformational leadership on follower development and performance: A field experiment. Academy of Management Journal, 45(4), 735-744.

Ehrhart, M. G. (2004). Leadership and procedural justice climate as antecedents of unit-level organizational citizenship behavior. Personnel Psychology, 57, 61-94.

Einstein, W. O., \& Humphreys, J. H. (2001). Transforming leadership: Matching diagnostics to leader behaviors. Journal of Leadership Studies, 1(8), 48-52.

Fiedler, F.E. (1996) „Research on Leadership Selection and Training: One View of the Future Administrative Science Quarterly, 41, 241-50

Gardner, L., \& C. Stough. (2002). Examining the relationship between leadership and emotional intelligence in senior level managers. Leadership and Organization Development Journal, 23(1-2), 68-78.

Hoffman, H. (2008). The mystery behind Millennials: What they can contribute, how they can prepare. Agribusiness Employer Guide, 8-9.

House, R. J., \& Shamir, B. (1993). Toward the integration of transformational, charismatic, and visionary theories. In M. Chemers \& R. Ayman (Eds.), Leadership theory and research: Perspectives and directions (pp. 81-107). New York, NY: Academic Pres

Huichun Yu, Peter Miller. (2005). Leadership style - The X Generation and Baby Boomers compared in different cultural contexts

Jensen, M., Kristina P, Sara C. (2020). A mixed-methods study of CEO transformational leadership and firm performance.

Johnson, M., \& Johnson, L. (2010). Generations inc.. New York: AMACOM.

Just, R. A (2011) The Differences In Leadership Styles Among Generation Cohorts Of Small Business Leaders And Their Relationship To Organizational Outcomes

Keller, R. T (2006) Transformational Leadership, Initiating Structure, and Substitutes for Leadership: A Longitudinal Study of Research and Development Project Team Performance

Kimball, L., \& Nick, C. (2006). How to improve employee motivation, commitment, productivity, well-being, and safety. Corrections Today, 68(3), 66-74

Kupperschmidt, B.R. (2000). Multigenerational Employees: Strategies for Effective Management. The Health Care Manager, 19, 65-76.

Lancaster L.C. \& Stillman D. (2002) When Generations Collide. Harper Business, New York, NY.

Lowe, K. B., Kroeck, K. G., \& Sivasubramaniam, N. (1996). Effectiveness correlates of transformational and transactional leadership: A meta-analytic review of the MLQ literature. The Leadership Quarterly, 7(3), 385-425.

Maika Jensen, Kristina Potočnik, Sara Chaudhry. (2020). A mixed-methods study of CEO transformational leadership and firm performance. 
Martin, C. A., \& Tulgan, B. (2002). Managing the generation mix, from collision to collaboration. Amherst, MA: HRD Press.

Masi, R. (2000). Effects of transformational leadership on subordinate motivation, empowering norms, and organizational productivity. International Journal of Organizational Analysis.

Mecca M. Salahuddin. (2010). Generational Differences Impact On Leadership Style And Organizational Success. University of the Incarnate Word, USA.

Northouse, P. G. (2004). Leadership theory and practice (3rd ed.). Thousand Oaks, CA: Sage.

Ogunola, A. A, Kalejaiye, P.O and Chiedu, A.A (2013) Management style as a correlate of job performance of employees of selected Nigerian brewing industries. African Journal of Business Management. Vol. 7 (36) 3714-3722

Strauss, W., \& Howe, N. (1991). Generations: The history of America's future, 1854 to 2069. New York, NY: William Morrow.

Tichy, N. M., \& Devanna, M. A. (1990). The transformational leader. New York, NY: Wiley.

Tsai, W.C., Chen, H.W. and Cheng, J.W. (2009) Employee Positive Moods as a Mediator Linking Transformational

Twenge, J. M., Campbell, W. K., \& Freeman, E. C. (2012). Generational differences in young adults' life goals, concern for others, and civic orientation, 1966-2009. Journal of Personality and Social Psychology, 102, 1045-1062.

Waldman, D. A., Bernard M. Bass, \& Francis J. Yammarino. (1990). Adding to Contingent Reward Behavior: The Augmenting Effect of Charismatic Leadership. Group \& Organization Studies, 15, 381-394.

Yukl, G. A. (2006). Leadership in organizations (6th ed.). Upper Saddle, NJ: Prentice Hall.Crumpacker, M., J.M. Crumpacker. Succession planning and Generational Stereotypes: Should HR Consider AgeBased Values and Attitudes a Relevant Factor or a Passing Fad? // Public Personnel Management, 2007. í v36. í pp. 349-369. 